\title{
乗捨て型共同利用交通システムに対する 利用権取引制度の設計とその解法の提案
}

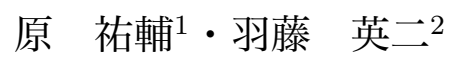 \\ ${ }^{1}$ 正会員 東北大学助教 未来科学技術共同研究センター（† 980-8579 宮城県仙台市青葉区荒巻字青葉 6-3-09) \\ E-mail: hara@plan.civil.tohoku.ac.jp \\ 2 正会員 東京大学大学院教授 工学系研究科社会基盤学専攻 ( $\bar{T} 113-8656$ 東京都文京区本郷 7-3-1) \\ E-mail: hato@bin.t.u-tokyo.ac.jp
}

\begin{abstract}
本研究は，乗捨て型共同利用型交通システムに対する利用権取引制度を提案する．乗捨て型共同利用交通シス テムは様々な利用者によって移動手段の時間的・空間的偏在を引き起こす可能性がある。この問題に対して, 最 適割当と価格設計を実現する利用権取引制度を構築する。本研究は上記の利用権取引制度を実現するために (1) 正直表明や効率性を担保するメカニズムデザインと，(2) 実適用のための割当問題の解法を示す．また，オーク ションによって決定する利用権価格特性の解析から, 利用権価格は車両移動による出発ノードの外部性と到着 ノードでの外部性の差額として解棌できることを示す。最後に，提案アルゴリズムが現実に想定される規模で 十分高速に計算できることを示す。
\end{abstract}

Key Words : mechanism design, combinatorial auctions, tradable permits, car-sharing

\section{1.はじめに}

近年，より柔軟性の高い移動の選択肢として，共同 利用型交通サービスが実社会で展開されている。たと えば，カーシェアリングや自転車共同利用システムは 日本国内においても事業者が参入し，実サービスとし て展開されている。しかし，既存のカーシェアリング は貸出場所と返却場所が同じであるラウンドトリップ が基本である。 また，乗捨て可能な自転車共同利用シ ステムは需要の偏りによる貸出ポートへの車両の集中 という問題がある。そのため，両者はともに自由な移 動の選択肢の提示という段階にはサービスが洗練され ていない.

そこで，本研究では乗捨て型共同利用交通システム の概念として，次の性質を有した交通システムを定義 する.

(a) 利用者が各車両をある時間内自由に使用可能な移 動の自由度を有している

（b）予め指定されたポートで乗捨て可能であり，交通 手段の補完性 (往路と復路の交通手段の一致) を解 消する

(c) 1 日内で複数の利用者を想定した 1 トリップ単位 の移動を指向する (レンタカーとは異なる)

（d）サービス供給者は車両のみ提供し，運転手を供給 しない (タクシーとは異なる)

しかし，乗捨て型共同利用交通システムには 1 ) 移動 需要の時間的-空間的偏りが引き起こす車両の偏在化,
2) ポートにおいて利用者間で車両を引渡す場合の時間 的-空間的マッチングの困難性といった問題が存在する. このような需給の時空間的ミスマッチを解消せずに運 用を行うと必ず非効率な資源配分が生ずる.

乗捨て型共同利用交通システムは効率的な資源配分 のために，社会的余剩を最大化するように利用者への 割当を行う必要がある。そのような効率的な割当を行 う方法として，利用者の移動需要に対する評価値を表 明させて, 最も評価值の高い利用者から割当を行う利 用権オークションメカニズムが考えられる。 しかし，単 純に時間帯別評価値が高い利用者に割り当てるだけで は各ポートにおいて全ての時間帯間で車両台数が一致 する時空間 OD 接続性は満たされない，そのため，乗捨 て型共同利用交通システムの最も効率的な運用は，時 空間 OD 接続性を満たすという制約条件下で社会的余 剩を最大化するような運用である。

乗捨て型共同利用交通システムのサービス提供者は, このような運用を実現するために事前に利用者の移動 需要について，その希望時間帯や利用 OD，そして各個 人の時間価值に伴う各サービスに対する金銭的な評価 值を必要とする。たとえば単純な事前予約システムに よってサービス提供者が移動需要に関する希望時間帯 や利用 OD のみを取得できた場合，時空間 OD 接続性 を満たすようにサービス運用を行うことは可能である が，効率性を満たすことはできない，そこで，乗捨て 型共同利用交通システムの利用権取引制度の必要性が 生まれる。 
このような乗捨て型共同利用交通システムの利用権 取引制度については，その市場をどのように設計すべ きかについて知見が存在していない，そこで，既存の オークション理論において良い性質をもつと知られて いる Vickrey-Clarke-Groves (VCG) メカニズムをベー スに，乗捨て型共同利用交通システムの利用権取引市 場を設計する。そして，その市場が持つ性質と数学的 性質を明らかにし，実現可能な利用権取引制度の設計 と実現可能性を示す。

本稿の構成は，以下の通りである．2.では，交通オー クションに関する既往研究を示し, 本研究の位置付け を明らかにする．3.では，本研究で扱う問題設定や利 用権取引制度を定義する，4.では，乗捨て型共同利用 交通システムの利用権取引制度としてVCGメカニズ ムを設計する．5.では，利用権取引制度における入札 行動による数学的性質の違いを明らかにし，利用権取 引制度における価格の交通的・経済学的解釈を行う。 6. では乗捨て型共同利用交通システムの利用権取引制度 を現実に適用可能とするための計算アルゴリズムを提 案し, 大規模な問題設定においても十分実用可能な計 算時間であることを示す，最後に，7.では，本研究の まとめと今後の課題を示す。

\section{2. 交通オークションに関する既往研究}

本研究で扱う交通サービスの利用権取引市場の先進 的な研究としてボトルネック通行権取引制度を挙げる ことができる．従来の混雑料金制度及び動的な課金入 キームを用いた動的混雑料金制度を最適に設計するた めには道路管理者と利用者の間に情報の非対称性が存 在するなど，多くの理論的課題が存在していた。それ に対して赤松ら ${ }^{1)}$, 赤松 ${ }^{2}$ では利用者情報の推定を必要 とせず，渋滞を考慮した交通施策としてネットワーク 通行権取引制度を提案している。この制度下において は交通渋滞は完全に抑制することが可能であり，また 動的混雑料金に対応する通行権価格は市場取引の結果 として決まるため, 情報の非対称性も解消される.さ らに，一般ネットワーク条件下において制度導入後の 均衡状態では社会的交通費用が最小となる社会的最適 状態に一致することを明らかにしている.

この制度における通行権取引市場の具体的なメカニズ ムとして和田・赤松3)では単一ボトルネックネットワー クにおける通行権取引市場のオークションメカニズム を，和田・赤松4)では一般ネットワークにおいて dayto-day アプローチを採用することで, 有限回で近似的 な社会的最適状態に導くメカニズムを提案している。

また, 組合せオークションの分野における本研究の位 置付けを記述する. 交通に関連する組合せオークション
の既往研究としては上記の通行権取引制度だけでなく, サプライ・チェーン・マネジメントの分野における物 流のパッケージ入札 (Porter et al. ${ }^{5}$; ; Moore, Warmke and Gorban ${ }^{6}$; Caplice and Sheffi ${ }^{7)}$ ) や空港のスロット 割当 (Ball, Donohue and Hoffman $\left.{ }^{8)}\right)$ などが存在する. これはどちらの例においても，買い手が入札する枠を 組み合わせる形のオークションであり，供給側は入札 值を最大化するように割当を決定すればよい，一方で， 乗捨て型共同利用交通システムにおいては利用者が望 むのはただ一つの枠であるが，その枠の利用において OD が存在し, 供給側が買い手の OD をうまく繋ぐよ うに割当を行う必要がある。つまり, 販売時点におい てはある時間帯のあらゆる OD に対する利用権枠が販 売されているが，割当後には割り当てられなかった OD の利用権が失われるという点で既存の組合せオークショ ンと異なる。

このような財の性質をもつた乗捨て型共同利用交通 システムの利用権オークションに対して, 利用時間帯枠 や希望 OD，その評価値に対して異質性のもつ利用者が 入札する場合に利用者が正直に自身の評価値を表明し (strategy-proof), 社会的余剩が最大化される (efficient) 割当を行うためのオークションメカニズムを設計した 点, またこの利用権オークションの数学的特性を明ら かにし, その解法の提案を行った点が本研究の独自性 である。

\section{3. 状況設定および乗捨て型共同利用交通シ ステム}

\section{(1) 分析対象とする交通空間条件}

本研究では任意のポート間移動が可能な乗捨て型共 同利用交通システムを分析対象とする. 現実の道路リン クを捨象したポート間移動のみ考えると, ある時間帯に 実現可能なトリップ OD は全てのポート間を結んだ完 全グラフ上で表される。このネットワークのノード集合 を $N$, 有向リンク集合を $L$ と書く。ノード集合 $N$ はそ の部分集合として利用者トリップの発生起点 (Origin) の集合 $O$, 終点 (Destination) の集合 $D$ を含む. $N$ の ノードは, 整数の連番 $k$ で区別され， $L$ のリンクはそ の上流ノード $p$ と下流ノード $q$ で区別される。つまり, 交通トリップの $\mathrm{OD} ヘ ゚ ア ~ p q$ の集合は $L$ で表される.

乗捨て型共同利用交通システムの設定を記述する。乗 捨て型共同利用交通システムは具体的にはカーシェア リングのような交通サービスを想定し, 利用者が行う トリップは図-1 に示すように 1 つの離散的な時間帯枠 $t$ の中で十分収まるようなトリップを対象としている. 1つの離散時間帯枠内に含まれない交通需要については レンタカーまたは乗捨てを許容しない既存のカーシェ 


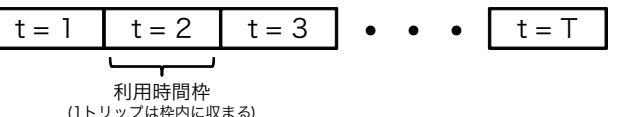

図-1 乗捨て型共同利用交通システムの利用時間枠の定義

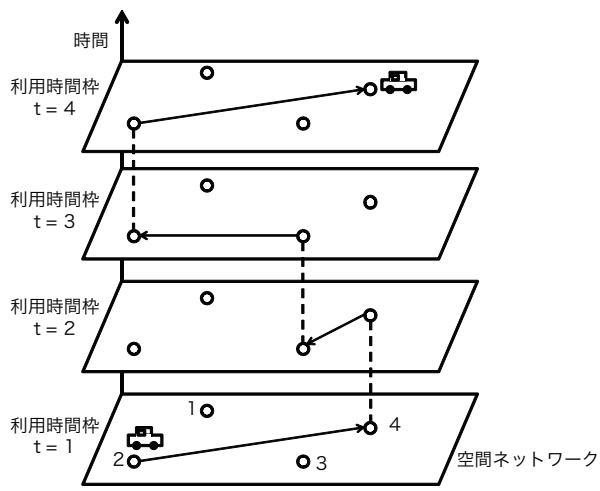

図-2 車両の時空間ネットワーク上の移動概念図

アリングサービスにより対応すると想定している。ま た，一般道路ネットワークで発生する渋滞や混雑によっ て生じる遅延が次時間帯枠に与える影響は無視し，す べての利用者は自身の利用時間枠内に予定した目的地 に到着するようなトリップとする。

乗捨て型共同利用交通システムでは $\mu$ 台の車両が供 給者から提供され，それぞれは独立に動くことができ る。ある 1 日の初期配置のみサービス提供者によって 準備されるが，別ポートへの配車のような行為はサー ビス提供者は行わず，利用者間の移動の接続のみで効 率的な車両活用が行わ机る。そのため，利用者の利用 段階では各車両は全ての利用時間帯枠間で時空間 OD 接続性が満たされるよう図-2のようにトリップが実現 される。

\section{(2) 行動主体}

本研究で分析するモデルに現れる主体は，乗捨て型 共同利用交通システム供給者と利用者である。サービ 又供給者は所有する車両を効率的に運用し，社会的余 剩の最大化を目指す主体である。乗捨て型共同利用交 通システムは各車両がトリップごとに独立に移動可能 なサービスであり，利用者の任意の $\mathrm{OD}$ 分布の下では 特定のポートに車両が集中してしまい，1 日の中で効率 的な運用がされない可能性がある。この問題には 1) 供 給者が再配車を行う，2) 車両ごとに全ての利用時間帯 枠間で OD 接続性を満たすという 2 つの解決法が存在 するが，1)の方法はカーシェアリング等の車両再配車 費用が大きな交通サービスにおいては供給側の維持管 理費用が大きい．そこで 2) の方法を実現するために， サービス供給者は所有する車両に対して，時間帯・OD 別の利用権を設定・発行し，必ず利用者が利用する時 点では発行された利用権に従って時間带枠間で車両が
OD 接続性を満たして運用する。ただし，1日の初期配 置のみサービス提供者によって準備される。

利用者は各自の希望 OD や希望時間帯枠をもつ て，1 回のトリップを行う主体である。各利用者を $i$ とし，その集合を $I$ とする。利用者は各々，乗 捨て型共同利用交通システムの利用権に対して希 望 $\mathrm{OD} p q$, 希望利用時間帯枠 $t$ に基づく評価値 $v_{p q}^{i}(t)$ をもつ. 利用者 $i$ の評価値ベクトルは $\boldsymbol{v}^{i}=$ $\left(v_{11}^{i}(1), v_{12}^{i}(1), \ldots, v_{1 N}^{i}(1), \ldots, v_{p q}^{i}(t), \ldots, v_{N N}^{i}(T)\right)$ で表 される。

なお，本研究では簡単化のため各利用者は希望 OD に代替性はなく，固定的であると仮定する。そのため， 利用者は自身の希望 OD 以外の利用権評価值はすべて 0であるとする.しかし, 複数の OD ペアに対して正の 評価值をもつ（目的地選択を行う）と本研究の以降の 議論の枠組みを拡張することも可能である．利用者は 乗捨て型共同利用交通システムを利用するためには利 用する時間帯・OD に対応する利用権を購入する必要が ある。利用者は自身の効用が最大となるような入札值 で入札を行い，落札できなかった場合（乗捨て型共同 利用交通システムを利用しない場合）は効用 $u_{a}^{i}$ となる 代替交通手段を選択することが可能であるとする.

\section{（3）利用者の効用の定義}

乗捨て型共同利用交通システムの利用者はそれぞれ 希望 OD や希望利用時間帯が異なるため, 各時間帯別, $\mathrm{OD}$ 別利用権に対する評価值 $v_{p q}^{i}(t)$ が異なる。これは 交通の観点から考えると, OD ゚゚ア $p q$ における交通費 用，時間帯 $t$ におけるスケジュール費用，代替交通手段 から得られる効用 $u_{a}$, 個人 $i$ の時間価值等によって決 まっている。しかし，一般的にこれらの要因の個別に 特定化することは容易ではない，そこで，本研究では 利用権オークションを用いることで，その評価值 $v_{p q}^{i}(t)$ を利用者 $i$ に直接表明させるメカニズムを考える.

代替交通手段から得られる効用 $u_{a}=0$ と基準化する と, 利用者 $i$ が OD ペア $p q$, 時間帯 $t$ に利用権から得 られる効用 $u_{p q}^{i}(t)$ は私的評価值 $v_{p q}^{i}(t)$ からオークショ ンで決定する利用権費用 $P_{p q}^{i}(t)$ を差し引いた擬似線形 (quasi-linear) 効用関数で表現されると仮定する.

$$
u_{p q}^{i}(t)=v_{p q}^{i}(t)-P_{p q}^{i}(t)
$$

代替交通手段から得られる効用 $u_{a}$ を 0 に基準化してい るため, 利用者は $u_{p q}^{i} \geq 0$ であれば乗捨て型共同利用 交通システムを利用する。

\section{（4）乗捨て型共同利用交通システムの利用権取引制度}

乗捨て型共同利用交通システムの利用権とは，予め 指定された OD を，予め指定された時間帯にのみ利用 可能な権利である. 本研究では, サービス供給者が, 各 
車両のすべての時間帯に対して，この OD 別・時間帯 別利用権を設定できる状況を想定し，後述の時空間 OD 接続性を満たすために, 利用権の割当者は利用をキャ ンセルすることはできないとする。すなわち，時間帯 $t$ に OD ペア $p q$ の利用を行えるのは時間帯 $t, \mathrm{OD}$ ペ ア $p q$ の利用権を持っている割当者のみであり, 割当者 は，必ずその OD ペアの移動を該当時間帯に行う必要 がある。

サービスの利用予定者は, 乗捨て型共同利用交通シ ステムの供給者が実施する利用権オークションにて, 利 用権を落札する必要がある。 ある 1 日の利用権の割当 は事前に（たとえば利用日前日に）一斉に利用権の割 当と利用権価格の決定が行われるため, サービス利用 予定者は割当実施時までに自身が利用したい（評価值 が 0 以上の) 利用権に対して入札を行う。そのため, 本 研究の枠組みでは, 当日に発生した突発的な利用需要 に関しては取り扱わない.

以降, サービス利用予定者であり, 利用権オークショ ンに参加する主体を入札者と呼ぶ，各入札者が乗捨て型 共同利用交通システムを利用可能であることを表す離散 変数として $x_{p q}^{i}(t) \in\{0,1\}$ を導入する. これは入札者 $i$ が時間帯 $t$ に OD ペア $p q$ に利用可能な利用権が割り当て られたとき 1 ，そうでなければ 0 をとる離散変数である. 評価值ベクトルと同様に, 入札者 $i$ の割当ベクトルは $\boldsymbol{x}^{i}=\left(x_{11}^{i}(1), x_{12}^{i}(1), \ldots, x_{1 N}^{i}(1), \ldots, x_{p q}^{i}(t), \ldots, x_{N N}^{i}(T)\right)$ で表される。また，入札者は 1 日に 1 回のトリップを 行う主体と仮定しているため, 複数以上の利用権を需 要しない. この単一需要 (single unit demand) 条件は

$$
\sum_{t \in T} \sum_{p q \in L} x_{p q}^{i}(t) \leq 1 \quad \forall i \in I
$$

\section{と表現される。}

この乗捨て型共同利用交通システムサービスでは車 両ごとにすべての利用時間帯で時空間 OD 接続性が満 たされるように利用権割当・サービス提供が行われる。 この時空間 OD 接続性条件は次式が成り立つことと等 しい.

$$
\begin{aligned}
& \sum_{i \in I} \sum_{p \in N} x_{p q}^{i}(t-1)+x_{q q}^{S}(t-1) \\
& =\sum_{i \in I} \sum_{p \in N} x_{q p}^{i}(t)+x_{q q}^{S}(t) \quad t=2 \cdots T, \forall q \in N
\end{aligned}
$$

ここで, $x_{q q}^{S}(t)$ は供給者が時間帯 $t$ に利用権を入札者に 配布せずに車両をノード $q$ に置き続ける台数を表す。

この式の左辺は時間帯 $t-1$ にノード $q$ に移動する車 両の数, つまり時間帯 $t-1$, ノード $q$ における集中交 通量を表し, 右辺は時間帯 $t$ にノード $q$ から移動する 車両の数, つまり時間帯 $t$, ノード $q$ における発生交通 量を表す。そして, $t \geq 2$ の全ての時間帯において, 任 意のノード $q$ において時空間 $\mathrm{OD}$ 接続条件が成り立つ

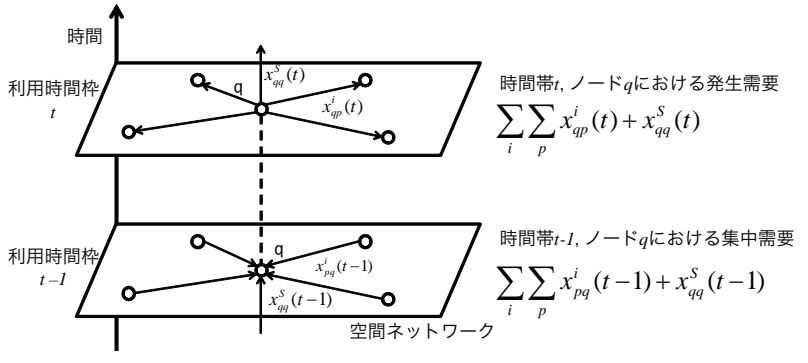

図-3 時空間 OD 接続条件

ていることを表している。この条件を時空間 OD 接続 条件を満たしていると呼ぶ。この関係性を簡単に図示 すると図-3のように表現される。

次に供給量制約を定義する。サービス供給者が提供 できる車両数が $\mu$ 台であるとする。このとき, サービス 供給者はある時間帯 $t$ における各 $\mathrm{OD} ヘ ゚ ア p q$ の時間帯 別利用権の総和がサービス供給者の提供車両台数 $\mu$ に 等しい枚数まで利用権を発行可能である。この乗捨て 型共同利用交通システムの各時間帯の容量制約条件は

$$
\sum_{i \in I} \sum_{p q \in L} x_{p q}^{i}(t)+\sum_{q} x_{q q}^{S}(t)=\mu \quad \forall t \in T
$$

で表される。しかし，この式は式 (3)の条件と合わせて 考えれば, $t=1$ の初期時点のみ容量制約条件を課すこ とで, 次の時間帯以降は自動的に容量制約条件は満た される. 従って, 初期時点 $(t=1)$ での容量制約条件と して次式で表現される。

$$
\sum_{i \in I} \sum_{p q \in L} x_{p q}^{i}(1)+\sum_{q} x_{q q}^{S}(1)=\mu
$$

サービス供給者が発行した乗捨て型共同利用交通シ ステム利用権は利用権オークションを通して利用者に 市場で販売される。利用予定者は利用権市場において, 希望する利用時間帯，OD に応じて必要となる利用権 に対して入札する。利用権オークションでは時間帯別・ $\mathrm{OD}$ 別利用権に対して, 次章で述べるオークションメカ ニズムに応じて, 利用権価格と割当者 (利用者) が決定 される。供給者が本システムで担う役割は，(1) 事前に 利用権オークションを実施し, 入札者から入札額の情 報を収集し, 次章のオークションメカニズムに応じて, 利用権の割当と価格決定を行うオークション管理者と しての役割と (2) 割当結果に応じて, $\mu$ 台の車両の時間 帯 $t=1$ の初期配置を行うことである.

\section{（5）実現目標とする社会的最適割当}

最後に，上記の設定の下で実現を目指す本システム の社会的最適状態を定義する。目標とする利用権割当 は社会的余剩を最大化する利用権割当である。ここで, 社会的余剩とは利用者および供給者の余剩の総和であ る. 利用権市場での金銭的取引はすべて主体間での所 得移転に過ぎないため, 社会的余剩を最大化する割当 
は，割り当てられた利用者 (落札者)の評価值の和が最 大となる割当である。そんのめ，上記の設定の下で社 会的余剩を最大とする利用者割当問題は，以下の制約 条件の下で落札者評価值の総和の最大化問題 $[\mathrm{SO}]$ とし て定式化できる。

$$
\max _{\boldsymbol{x}} \sum_{i \in I} \sum_{t \in T} \sum_{p q \in L} v_{p q}^{i}(t) x_{p q}^{i}(t)
$$

subject to

$$
\begin{aligned}
& \sum_{i \in I} \sum_{p q \in L} x_{p q}^{i}(1)+\sum_{q} x_{q q}^{S}(1)=\mu \\
& -\sum_{i \in I} \sum_{p \in N} x_{p q}^{i}(t-1)-x_{q q}^{S}(t-1) \\
& +\sum_{i \in I} \sum_{p \in N} x_{q p}^{i}(t)+x_{q q}^{S}(t)=0 \\
& t=2 \cdots T, \forall q \in N \\
& \sum_{t \in T} \sum_{p q \in L} x_{p q}^{i}(t) \leq 1 \quad \forall i \in I \\
& x_{p q}^{i}(t) \in\{0,1\} \quad \forall p q \in L, \forall i \in I, \forall t \in T \\
& x_{q q}^{S}(t) \in N \quad \forall q \in N, \forall t \in T
\end{aligned}
$$

この問題は，乗捨て型共同利用交通システムの供給量 制約 (7), 各時間帯・各ポートにおける時空間 OD 接続 条件 (8), 各利用者が乗捨て型共同利用交通システムを 最大 1 回需要する単一需要条件 (9), 各利用者の 0-1 利 用権割当 $(10)$ の下で割当者の評価值の和が最大となる 利用権割当を求める問題であり, これは組合せ最適化 問題の一種である.

この問題は行列表現を行うと, 以下のようにコンパ クトに書くことができる.

$$
\begin{aligned}
\max _{\boldsymbol{x}} \boldsymbol{v} \cdot \boldsymbol{x} & \\
\text { subject to } \quad & A \boldsymbol{x} \leq \boldsymbol{b} \\
& \boldsymbol{x}^{i} \in\{0,1\} \quad \forall i \\
& \boldsymbol{x}^{s} \in \boldsymbol{N}
\end{aligned}
$$

ここで，表記上，供給者がノードに置き続ける場合の割 当ベクトルを $\boldsymbol{x}^{S}=\left(x_{11}^{S}(1), \ldots, x_{q q}^{S}(T)\right)$, 便宜上の評 価值ベクトルを $\boldsymbol{v}^{S}=\left(v_{11}^{S}(1), \ldots, v_{q q}^{S}(T)\right)=\mathbf{0}$ とする. このとき, 全主体の割当ベクトルは $\boldsymbol{x}=\left(\boldsymbol{x}^{1}, \ldots, \boldsymbol{x}^{S}\right)$, 評価值ベクトルは $\boldsymbol{v}=\left(\boldsymbol{v}^{1}, \ldots, \boldsymbol{v}^{S}\right)$ と書ける。.また，式 (13) の制約条件行列 $A$, ベクトル $\boldsymbol{b}$ は図-4 の構造をし ている.

しかし，利用権オークションによって，サービス供 給者が最適化問題 $[\mathrm{SO}]$ を実際に解き, 最適な利用権の 割当を決定するには 2 つの問題点がある。一つ目は問 題 [SO] はサービス供給者が各利用者の評価値 $v_{p q}^{i}(t)$ を 正確に観測できた場合に初めて解くことが可能となる 問題であるため, 評価値の正直表明性を担保する必要 がある点である。たと光ば利用者が戦略的な入札（自 身の評価値よりも低く入札する，高く入札する等）を

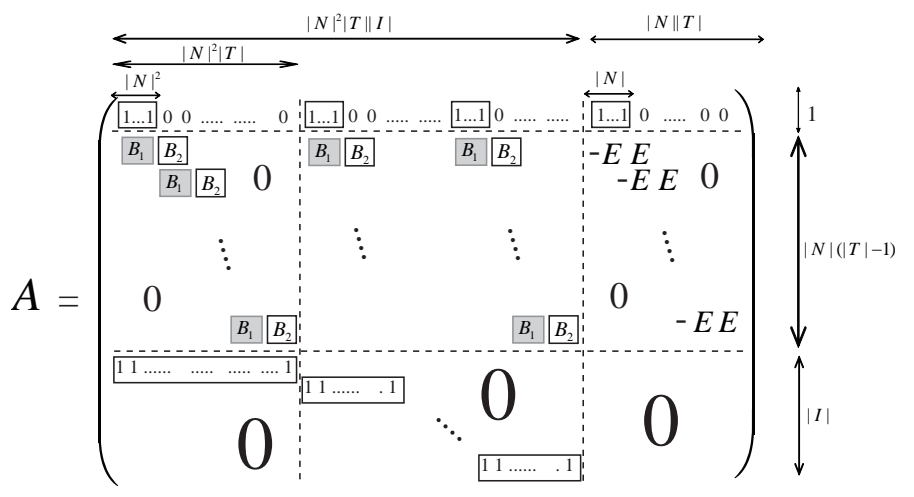

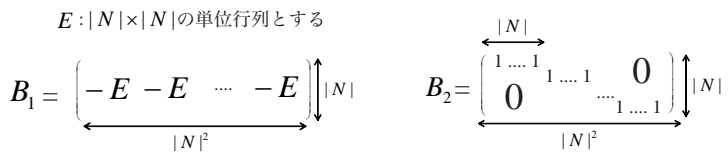

$$
\begin{aligned}
& \mathbf{b}^{T}=\underset{1}{\stackrel{(\mu, 0,0, \ldots, 0,1, \ldots, 1)}{\longleftrightarrow}}
\end{aligned}
$$

図-4 問題 [SO] の制約条件行列 $A$ とベクトル $\boldsymbol{b}$

行った場合，サービス供給者のもとに集まった入札值 情報で上記の割当問題を考えたとしても当然，社会的 余剩を最大化できる保証は存在しない. 二つ目の問題 点は正しい評価值を観測できたとしても, 組合わせ最 適化問題は NP 困難であり, 求解にかかる時間が多項 式時間とは限らないという NP 困難性である。そこで, 本稿では一つ目の正直表明性に対して 4. で，二つ目の NP 困難性に対しては 5., 6. で対応し，この乗捨て型共 同利用交通システムの利用権オークションを実行可能 とする。

\section{VCG メカニズムの設計}

本章では，社会的最適状態を達成するためのメカニ ズムを組合せオークションの枠組みを用いて構築する. 組合せオークションは，単一財オークションを組み合わ せ入札可能に拡張した枠組みであり, 本研究のように 利用権間に補完性があるような財を扱う場合に有用で ある。本研究では組合せオークションのベンチマーク であるVCGメカニズムを用いた利用権市場を構築し， そのメカニズム下においては社会的最適状態が達成で きることを示す。

\section{（1） 利用権オークションの VCG メカニズムとその 性質}

VCGメカニズムは Vickrey ${ }^{9}$ )の同種複数財のオーク ションからはじまるオークション・メカニズムであり, Clarke $^{10)}$, Groves ${ }^{11)}$ の公共財に関する研究により, 異 種複数財を扱えるメカニズムへと一般化された (Krishna and Perry $\left.^{12)}\right)$. そこで, 乗捨て型共同利用交通システ 
ムの利用権オークションで適用可能な VCGメカニズム の設計を行う。

時空間 OD 接続条件を満たす乗捨て型共同利用交通 システムの利用権取引制度に対する VCGメカニズム は次のように設計できる。

(a) 入札者は入札しうる全ての利用権に入札を行う。

（b）オークション管理者（サービス供給者）は，時空 間 OD 接続制約や供給量制約の下で割当者の入札 值の和が最大になるように, 利用権の割当者を決 定する.

(c) 利用権を落札した入札者の支払額 (利用権価格) は, 割当者が入札することで生じる他者の社会的余剩 の減少分とする。

VCG メカニズムは一般的に次のような良い性質をも つことが知られている。(1) 各利用者にとって, 自分 の真の評価値を正直に申告することが支配戦略となる (strategy-proof), (2) 効率的な資源配分が達成できる. 時空間 OD 接続制約や供給量制約といつた乗捨て型共 同利用交通システム特有の制約下においても次の命題 1 は成立する。

命題 1 乗捨て型共同利用交通システムの利用権取引制 度は時空間 OD 接続性の制約下での VCG メカニズム を設計することで効率性と耐戦略性を満たすことがで きる

\section{(証明：付録 I 参照)}

乗捨て型共同利用交通システムの利用権オークション においても VCGメカニズムを設計することで, 効率性 と耐戦略性を満たすことが示すことができる．以上よ り, 利用権オークションによって, サービス供給者が最 適な利用権割当を行うための一つ目の問題点である正 直表明性を担保することができた。

次に, VCGメカニズム下において利用権オークショ ンで落札者が支払う価格を記述する，全入札者による 入札值ベクトルを $\boldsymbol{v}$, その条件下で割当者による入札 值の和を最大にする割当を表すべクトルを $S(\boldsymbol{v})$ とし， $S^{i}(\boldsymbol{v})=\{0,1\}$ は個人 $i$ の割当結果を表すとする．この とき, VCG メカニズムにおける個人 $i$ の支払額 $P^{i}(v)$ は次の式で表される。

$$
P^{i}(\boldsymbol{v})=W\left(0, \boldsymbol{v}^{-i}\right)-W^{-i}(\boldsymbol{v})
$$

ここで, $\boldsymbol{v}^{-i}$ は個人 $i$ 以外の入札者の入札值ベクトル, $W(\cdot)$ は入札值ベクトルによる割当結果 $S(\cdot)$ の下での 割当者による入札值の和を表し, $W^{-i}(\cdot)$ は $W(\cdot)$ の割 当結果から個人 $i$ を取り除いた場合の割当者による入 札值の和を表す。この支払額はVickrey payments と呼 ばれ, 個人 $i$ が $v^{i}$ の入札值ベクトルで入札することで, システム全体の効率性（個人 $i$ 以外の入札者による社 会的余剩）に与える外部性を表す。
土木学会論文集D3 (土木計画学), Vol. 70, No. 4, 198-210, 2014.

サービス供給者はオークション管理者として，上記 のVCG メカニズムに基づいて (1) 利用権の割当を決 める勝者決定問題の解を求める, (2) 利用権価格 (Vickrey payments)の計算を行うという 2 つ計算を行う必 要がある。この勝者決定問題 (Winner Determination Problem) は最適化問題 $[\mathrm{SO}]$ そのものであり, ここで 問題 $[\mathrm{SO}]$ の二つ目の問題である組合わせ最適化問題の $\mathrm{NP}$ 困難性を解決する解法を提案する必要がある。この 問題について, 次章で入札者の入札行動を分類するこ とで, 利用権オークションの勝者決定問題の数学的性 質を解析する。

\section{5. 入札行動とオークションの性質}

\section{(1) 単一入札と複数入札}

3. に記述したように，入札者は自分の評価値が 0 以 上となる 1 つ以上の時間帯別利用権に同時に入札を行う と仮定した。これは同一 OD に対する複数の時間帯の 利用権に同時に入札しているため, 複数入札と呼ぶ. 一 方で, どの入札者もただ一つの時間帯の利用権にのみ入 札する (ただ一つの時間帯の利用権にしか入札すること ができない) と仮定した状態を単一入札 (single-minded bid) と呼ぶ. 組合せオークションの分野において, 単 一入札を仮定した問題は数学的に良い性質を持ってい ることが知られている (Blumrosen and $\mathrm{Nisan}^{13)}$ ).

本稿で扱う問題は複数の時間帯枠に入札する複数入 札のケースである. しかし, 単一入札のケースを考える ことは問題 $[\mathrm{SO}]$ の数学的性質を明らかにし, その NP 困難性を解決するために有用である。 そこで, まず, 単 一入札のケースを考えて, 乗捨て型共同利用交通シス テムの利用権オークションの問題構造を明らかにしょ う。本研究では簡単のため, 各入札者は単一入札の場 合は自身の評価值の最大の時間帯の利用権に対して入 札を行うと仮定するが, 任意の一つの利用権に対して 入札を行うと仮定しても，一般性は失われない.

\section{(2) 特徵的な数值例}

これまで考えてきた複数入札と単一入札の結果の違 いを如実に表す例として, 複数入札時には表 -1 で示さ れる入札值で, 単一入札時には表-2 で示す入札值で実 施される利用権オークションを考えよう。オークショ ンの落札者集合を $\mathbf{W}_{\mu}$ とする. 車両台数が $\mu=3$ の場 合, 表-3で示すように, 全入札者が自身にとって最大 の評価値にのみ入札する単一入札の場合では割当者は $\mathbf{W}_{3}=\{\{15,5,18\},\{19,12,17\},\{4,21,13\}\}$, 社会的余 剩は 833 となる。一方, 複数入札では 3 台の車両の割 当者は $\mathbf{W}_{3}=\{\{15,5,18\},\{19,13,17\},\{4,21,10\}\}$ と なり，社会的余剩は 837 である。 
表-1 複数入札時に入札される全入札者の評価値

\begin{tabular}{ccccc}
\hline 入札者 & $\mathrm{OD}$ & $v(t=1)$ & $v(t=2)$ & $v(t=3)$ \\
\hline 1 & $1 \rightarrow 2$ & 41 & 31 & 21 \\
2 & $1 \rightarrow 2$ & 25 & 30 & 20 \\
3 & $1 \rightarrow 2$ & 27 & 32 & 37 \\
\hline 4 & $1 \rightarrow 3$ & 89 & 79 & 69 \\
5 & $1 \rightarrow 3$ & 88 & 93 & 83 \\
6 & $1 \rightarrow 3$ & 70 & 75 & 65 \\
7 & $1 \rightarrow 3$ & 52 & 57 & 62 \\
\hline 8 & $2 \rightarrow 1$ & 93 & 83 & 73 \\
9 & $2 \rightarrow 1$ & 61 & 66 & 56 \\
10 & $2 \rightarrow 1$ & 83 & 88 & 93 \\
\hline 11 & $2 \rightarrow 3$ & 76 & 66 & 56 \\
12 & $2 \rightarrow 3$ & 78 & 83 & 73 \\
13 & $2 \rightarrow 3$ & 87 & 92 & 97 \\
14 & $2 \rightarrow 3$ & 75 & 80 & 85 \\
\hline 15 & $3 \rightarrow 1$ & 97 & 87 & 77 \\
16 & $3 \rightarrow 1$ & 73 & 78 & 68 \\
17 & $3 \rightarrow 1$ & 88 & 93 & 98 \\
18 & $3 \rightarrow 1$ & 75 & 80 & 85 \\
\hline 19 & $3 \rightarrow 2$ & 99 & 89 & 79 \\
20 & $3 \rightarrow 2$ & 82 & 72 & 62 \\
21 & $3 \rightarrow 2$ & 86 & 91 & 81 \\
22 & $3 \rightarrow 2$ & 59 & 64 & 69 \\
\hline
\end{tabular}

表-2 単一入札時に入札される全入札者の評価値

\begin{tabular}{ccccc}
\hline 入札者 & OD & $v(t=1)$ & $v(t=2)$ & $v(t=3)$ \\
\hline 1 & $1 \rightarrow 2$ & 41 & - & - \\
2 & $1 \rightarrow 2$ & - & 30 & - \\
3 & $1 \rightarrow 2$ & - & - & 37 \\
\hline 4 & $1 \rightarrow 3$ & 89 & - & - \\
5 & $1 \rightarrow 3$ & - & 93 & - \\
6 & $1 \rightarrow 3$ & - & 75 & - \\
7 & $1 \rightarrow 3$ & - & - & 62 \\
\hline 8 & $2 \rightarrow 1$ & 93 & - & - \\
9 & $2 \rightarrow 1$ & - & 66 & - \\
10 & $2 \rightarrow 1$ & - & - & 93 \\
\hline 11 & $2 \rightarrow 3$ & 76 & - & - \\
12 & $2 \rightarrow 3$ & - & 83 & - \\
13 & $2 \rightarrow 3$ & - & - & 97 \\
14 & $2 \rightarrow 3$ & - & - & 85 \\
\hline 15 & $3 \rightarrow 1$ & 97 & - & - \\
16 & $3 \rightarrow 1$ & - & 78 & - \\
17 & $3 \rightarrow 1$ & - & - & 98 \\
18 & $3 \rightarrow 1$ & - & - & 85 \\
\hline 19 & $3 \rightarrow 2$ & 99 & - & - \\
20 & $3 \rightarrow 2$ & 82 & - & - \\
21 & $3 \rightarrow 2$ & - & 91 & - \\
22 & $3 \rightarrow 2$ & - & - & 69 \\
\hline
\end{tabular}

2 つの入札方式の違いとして，単一入札のケースにお ける社会的最適状態は必ず複数入札における社会的最 適状態以下となる。この理由として, 複数入札時に存 在していた利用権枠の入札值が単一入札時には存在し ていないため，割当ベクトル $\boldsymbol{x}$ が取ることのできる空 間が複数入札時に比べて, 小さくなっているためであ る. その結果として, 複数入札時と単一入札時の落札 者が異なる可能性がある。この数值例では, 図-5で示
表 -3 単一入札と複数入札による割当結果の違い

\begin{tabular}{c|ccccccccc}
\hline 単一 & {$[15$} & 5 & $18]$ & {$[19$} & 12 & $17]$ & {$[4$} & 21 & $13]$ \\
\hline $\mathrm{O}$ & 3 & 1 & 3 & 3 & 2 & 3 & 1 & 3 & 2 \\
$\mathrm{D}$ & 1 & 3 & 1 & 2 & 3 & 1 & 3 & 2 & 3 \\
$v$ & 97 & 93 & 85 & 99 & 83 & 98 & 89 & 91 & 97 \\
\hline 複数 & {$[15$} & 5 & $18]$ & {$[19$} & 13 & $17]$ & {$[4$} & 21 & $10]$ \\
\hline $\mathrm{O}$ & 3 & 1 & 3 & 3 & 2 & 3 & 1 & 3 & 2 \\
$\mathrm{D}$ & 1 & 3 & 1 & 2 & 3 & 1 & 3 & 2 & 1 \\
$v$ & 97 & 93 & 85 & 99 & 92 & 98 & 89 & 91 & 93 \\
\hline
\end{tabular}
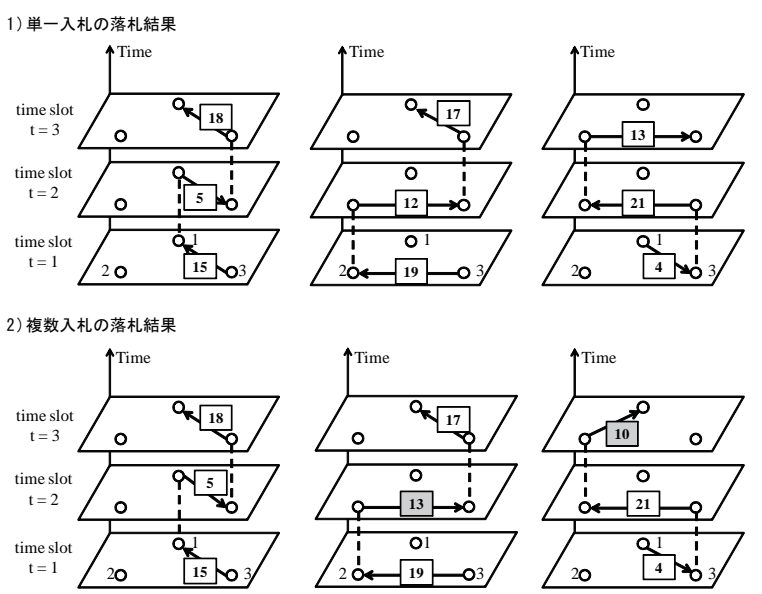

図-5 単一・複数入札時の落札者とその経路

すように，単一入札時に落札していた入札者 $\mathrm{ID}=12$ の 代わりに, 複数入札時では入札者 $\mathrm{ID}=13$ の割当時間帯 が変更され，新たに入札者 $\mathrm{ID}=10$ が落札している．当 然, 複数入札の割当に一致する単一入札は存在するが, この例における入札者 $\mathrm{ID}=13$ が時間帯 $t=3$ ではなく $t=2$ に入札する行動を各個人が他者の入札值も知るこ となく行うことは難しい.

このように，入札者が複数の利用権に対して正の評 価值をもつ場合, 単一入札による割当結果は, 複数入 札による割当結果と比べて, 社会的余剰 (割当者の評価 值の総和) が小さくなる可能性が存在する．また，単一 入札の結果と複数入札と一致させる入札行動を事前に 入札者に行わせることは難しい. そのため, オークショ ンメカニズムとしては, 複数入札を許容する必要があ る.しかし, 次節で述べるように, 単一入札オークショ ンは数学的に良い性質があるため, まず単一入札オー クションの問題構造を分析する.

\section{(3) 単一入札オークションと LP 緩和}

単一入札を仮定した状態における問題 $[\mathrm{SO}]$ は次のよ うな問題 $[\mathrm{SO}-\mathrm{SMB}]$ に書き換えられる。

$$
\max _{\boldsymbol{x}} \sum_{i \in I} \sum_{t \in T} \sum_{p q \in L} v_{p^{i} q^{i}}^{i}\left(t^{i}\right) x_{p^{i} q^{i}}^{i}\left(t^{i}\right)
$$


subject to

$$
\begin{aligned}
& \sum_{i \in I} \sum_{p q \in L} x_{p^{i} q^{i}}^{i}(1)=\mu \\
& -\sum_{i \in I} \sum_{p \in N} x_{p^{i} q^{i}}^{i}(t-1)+x_{q q}^{S}(t-1) \\
& +\sum_{i \in I} \sum_{p \in N} x_{q^{i} p^{i}}^{i}(t)+x_{q q}^{S}(t)=0 \\
& \quad \forall t=2, \ldots T, \forall q \in N \\
& x_{p^{i} q^{i}}^{i}\left(t^{i}\right) \in\{0,1\} \quad \forall p q \in L, \forall i \in I, \forall t \in T \\
& x_{q q}^{S}(t) \in N \quad \forall q \in N, \forall t \in T
\end{aligned}
$$

ここで, 各個人 $i$ の評価值は $v_{p^{i} q^{i}}^{i}\left(t^{i}\right)$, 割当は $x_{p^{i} q^{i}}^{i}\left(t^{i}\right)$ である. 3. (2) で定義したように，複数入札時の入札 者 $i$ の評価值ベクトルは

$\boldsymbol{v}^{i}=\left(v_{11}^{i}(1), v_{12}^{i}(1), \ldots, v_{1 N}^{i}(1), \ldots, v_{p q}^{i}(t), \ldots, v_{N N}^{i}(T)\right)$

であり, 個人ごとに $|N|^{2}|T|$ の要素 (評価值) を持つが, 単一需要を表す制約条件 $(9)$

$$
\sum_{t \in T} \sum_{p q \in L} x_{p q}^{i}(t) \leq 1 \quad \forall i \in I
$$

によって, オークション割当時には一つ以下の割当結果 が与えられる。一方, 単一入札オークションでは最初か ら個人 $i$ は $v^{i}=v_{p^{i} q^{i}}^{i}\left(t^{i}\right)$ の一つの要素のみオークショ ンに入札值として与えられ, 割当結果も $x^{i}=x_{p^{i} q^{i}}^{i}\left(t^{i}\right)$ の一つの要素が存在するのみである。このように, 単 一入札時の割当問題 $[\mathrm{SO}-\mathrm{SMB}]$ は元問題 $[\mathrm{SO}]$ から単一 需要条件 $(9)$ を取り除いたものとなる.

この整数計画問題の解を求めるのに線形計画 (LP) 緩 和を行うことを考える。このとき, 評価值ベクトル $\boldsymbol{v}$, 割当ベクトル $\boldsymbol{x}$ は

$$
\begin{aligned}
& \boldsymbol{v}=\left(v_{p^{1} q^{1}}^{1}\left(t^{1}\right), v_{p^{2} q^{2}}^{2}\left(t^{2}\right), \ldots v_{p^{n} q^{n}}^{n}\left(t^{n}\right), \boldsymbol{v}^{S}\right) \\
& \boldsymbol{x}=\left(x_{p^{1} q^{1}}^{1}\left(t^{1}\right), x_{p^{2} q^{2}}^{2}\left(t^{2}\right), \ldots x_{p^{n} q^{n}}^{n}\left(t^{n}\right), \boldsymbol{x}^{S}\right)
\end{aligned}
$$

と書くことができる.

式 (17) の LP 緩和を行った最適化問題 [SO-SMB-LP] を行列表現すると次のように書ける.

$$
\begin{aligned}
\max _{\boldsymbol{x}} \boldsymbol{v} \cdot \boldsymbol{x} & \\
\text { subject to } \quad A \boldsymbol{x} & \leq \boldsymbol{b} \\
\boldsymbol{x} & \geq 0
\end{aligned}
$$

ここで, 制約条件行列 $A$ は図-6の構造をしている。こ の制約条件行列 $A$ が完全ユニモジュラ行列 (totally unimodular matrix: TUM) であれば，LP 緩和問題の解は 整数解となる (元の整数計画問題の解と一致する) こと が知られている14),15)。 ここで，次の命題が成り立つ.

命題 2 問題 [SO-SMB] の LP 緩和問題 [SO-SMB-LP] の制約条件行列は完全ユニモジュラ行列である.

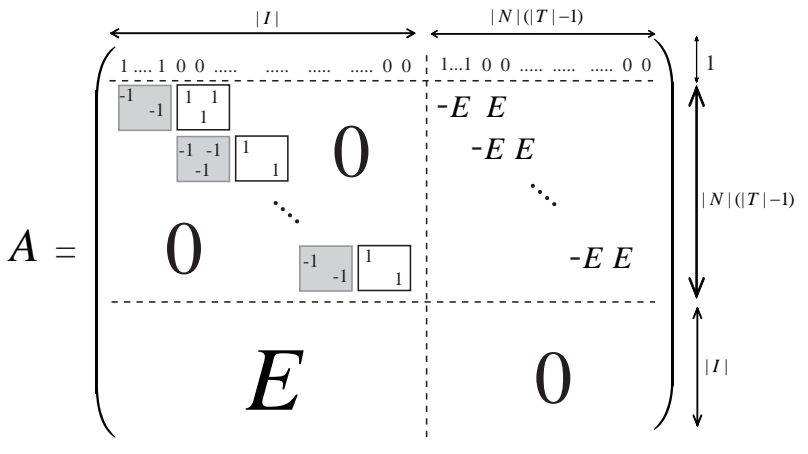

図-6 問題 $[S O-S M B-L P]$ の制約条件行列

\section{証明}

制約式 (15), (16) はフロー保存則を表す接続行列であ り, 行列 $A$ の 1 行目から $|N|(|T|-1)+1$ 行目に対応し ている.この行列は完全ユニモジュラ行列である (see コルテ・フィーゲン16), p.140). また, 制約式 (17) は 単位行列であり, 完全ユニモジュラ行列と単位行列を 結合した行列もまた, 完全ユニモジュラ行列である17). 以上より命題 2 が証明される.

以上より, 最適化問題 $[\mathrm{SO}-\mathrm{SMB}]$ は最適化問題 [SOSMB-LP] を解析することで問題の性質が得られる.

\section{（4）オークション価格の解釈}

4.1 (1) で示した通り，VCGメカニズムによって決 定される入札者 $i$ の支払価格は $P^{i}(\boldsymbol{v})=W^{-i}\left(0, \boldsymbol{v}^{-i}\right)-$ $W^{-i}(\boldsymbol{v})$ にで表される. そこで, 問題 $[\mathrm{SO}-\mathrm{SMB}-\mathrm{LP}]$ を 用いて乗捨て型共同利用交通システムの利用権オーク ションの価格を交通の観点から解釈する.

最適化問題 $[\mathrm{SO}-\mathrm{SMB}-\mathrm{LP}]$ の双対問題を考えよう. 式 (15) に対応する双対変数を $P(1)$, 式 (16) に対応する双 対変数を $P_{q}(t)$, 式 $(17)$ に対応する双対変数を $u^{i}$ とする と, 双対変数 $\boldsymbol{y}=\left(P(1), P_{1}(2), \ldots, P_{q}(T), u^{1}, \ldots, u^{I}\right)$ とできる。このとき，双対問題は

$$
\begin{gathered}
\max _{\boldsymbol{y}} \boldsymbol{b}^{T} \cdot \boldsymbol{y} \\
\text { subject to } \quad A^{T} \boldsymbol{y} \geq \boldsymbol{v} \\
\boldsymbol{y} \geq 0
\end{gathered}
$$

と表される。ここで，これらを要素表示すると，

$$
\min _{P(1), \boldsymbol{u}} \mu \cdot P(1)+\sum_{i \in I} u^{i}
$$

subject to

$$
\begin{array}{ll}
P_{p^{i}}\left(t^{i}\right)-P_{q^{i}}\left(t^{i}+1\right)+u^{i} \geq v^{i} & \forall i \in I \\
P(1)-P_{q}(2) \geq 0 & \forall q \in N \\
P_{p}(t-1)-P_{q}(t) \geq 0 & \forall p, q \in N, t=3, \ldots T \\
\boldsymbol{P} \geq \mathbf{0}, \quad \boldsymbol{u} \geq \mathbf{0} &
\end{array}
$$


ここで，個人 $i$ の入札した時間帯を $t^{i}$ ，出発ノードを $p^{i}$, 到着ノードを $q^{i}$ とする. 制約式 $(22)$ を次式のよう に変形する。

$$
u^{i} \geq v^{i}-\left(P_{p^{i}}\left(t^{i}\right)-P_{q^{i}}\left(t^{i}+1\right)\right)
$$

この式と式(1) を比較することにより，この双対変数 $u^{i}$ を個人 $i$ の効用と解釈し, $P_{p}(t), P_{q}(t+1)$ を時間帯 $t$ にポート $p$ を出発するための価格, 時間带 $t+1$ にポー 卜 $q$ を出発するための価格と解釈すると, 個人 $i$ の効 用最大化行動を表していることが示される. 同様に式 (23) は時間帯 1 に出発するための価格は時間帯 2 の任 意ノードにおけるの出発するための価格よりも高いこ とを表し, 式 $(24)$ は時間帯 $t$ にノード $p$ を出発するた めの価格は時間帯 $t+1$ にノード $q$ を出発するための価 格よりも高いことを表す．以上より，この双対問題の目 的関数 (21) は車両台数 $\mu$ と時間帯 1 の出発価格の積と 全個人の効用の総和の和であり, 第 1 項は供給者の収 益, 第 2 項は消費者余剩を表していることがわかる.

乗捨て型共同利用交通システムの VCG メカニズム によって決定される, 式 (1)の乗捨て型共同利用交通シ ステムの利用権価格 $P_{p q}(t)$ と式 (26) の比較より,

$$
P_{p q}(t)=P_{p}(t)-P_{q}(t+1)
$$

が成り立つ。ここから, 利用権価格の意味を考察する。 本稿の問題設定ではサービス供給者が乗捨て型共同利 用交通システムの利用権をオークションにて販売し, 利 用者はその利用権を購入するのみである。にもかかわら ず，利用権の落札者は時間帯 $t$ のポート出発価格 $P_{p}(t)$ を支払い, 次の時間帯のポート出発価格 $P_{q}(t+1)$ を受 け取っている。また，サービス供給者は最初の時間帯 の出発価格 $P(1)$ のみ受け取っており, 時間帯 $t=2$ 以 降は時間帯・ポート間での個人のマッチングを行って いるのみである。

利用権を割り当てられた利用者は自身が利用する時 間帯 $t$, ポート $p$ において, 乗捨て型共同利用交通シス テムのポート出発価格 $P_{p}(t)$ を支払うが，ポート $q$ に到 着した際に次の利用者が支払うポート出発価格 $p_{q}(t+1)$ を受け取る。これは，この交通サービスのある利用者 による車両移動は，次の利用者にとっては，自分のた めに車両を運んできたと解釈することができるためで ある。このように，乗捨て型共同利用交通システムの 利用権オークションは車両移動の外部性をポート出発 価格に内生化し，それぞれの OD 需要を接続すること で各ポートでの時間帯別の出発する権利を利用者間で 取引するように，価格が VCG メカニズムによって決定 されている.

\section{（5）複数入札オークションの性質}

単一入札のケースでは，元問題を LP 緩和した問題の 制約条件行列が完全ユニモジュラ行列であるため, LP 問題を解くことで元問題と同じ整数解が得られること を示した．また，双対問題を考えることで，乗捨て型共 同利用交通システムの利用権価格が Vickrey payments であるだけでなく，ポート出発時の支払額とポート到 着時の収益に分解され, 各利用者は車両移動の外部性 によって消費者であり, 生産者でもあることを示した。

次に, 複数入札オークションの場合を考えよう. 式 (12), (13) で示した最適化問題 [SO]の LP 緩和問題 [SOLP] は

$$
\begin{aligned}
\max _{\boldsymbol{x}} \boldsymbol{v} \cdot \boldsymbol{x} \\
\text { subject to } \quad A \boldsymbol{x} \leq \boldsymbol{b} \\
\boldsymbol{x} \geq 0
\end{aligned}
$$

の制約条件行列は図-4で示される $A$ と同じである。し かし, 複数入札は単一入札と異なり, 次の命題が成り 立つ。

命題 3 問題 $[\mathrm{SO}]$ の LP 緩和問題 [SO-LP] の制約条件 行列は完全ユニモジュラ行列ではない.

\section{証明}

行列 $A$ が完全ユニモジュラ行列であることの定義は行 列 $A$ のどの小行列式も $0,+1,-1$ のいずれかであるこ とである. 問題 $[\mathrm{SO}-\mathrm{LP}]$ の制約条件行列 $A$ から， 1 行 目 (供給量制約条件), 2 行目 (時空間 OD 接続条件の 1 行目), $|N|(|T|-1)+2$ 行目 (単一需要条件の 1 行目) と 1 列目, $|N|^{2}+1$ 列目, $|N|^{2}|T|+1$ 列目を取り出し た小行列式を考えよう。この小行列式は

$$
\left|\begin{array}{ccc}
1 & 0 & 1 \\
-1 & 1 & 0 \\
1 & 1 & 0
\end{array}\right|=2
$$

である，以上より，問題 $[\mathrm{SO}-\mathrm{LP}]$ の制約条件行列 $A$ は 完全ユニモジュラ行列ではない.

命題 3 より, LP 緩和では整数解が得られる保証がな い. そのため, 本稿が考えている一般的な（複数入札 を許容する）利用権オークションの勝者決定問題を解 くには二つ目の問題点である NP 困難性が解消されて いない. しかし, 単一入札と同様, 複数入札における $\mathrm{LP}$ 緩和問題 $[\mathrm{SO}-\mathrm{LP}]$ の双対問題を考えてみよう。

\section{（6）複数入札における LP 緩和問題の双対問題}

単一入札と同様，式 (7) に対応する双対変数を $P(1)$, 式 (8) に対応する双対変数を $P_{q}(t)$, 式 (9) に 対応する双対変数を $u^{i}$ とすると, 双対変数 $\boldsymbol{y}=$ $\left(P(1), P_{1}(2), \ldots, P_{q}(T), u^{1}, \ldots, u^{I}\right)$ とできる。このと 
き，双対問題は

$$
\begin{array}{cc}
\max _{\boldsymbol{y}} \boldsymbol{b}^{T} \cdot \boldsymbol{y} \\
\text { subject to } \quad A^{T} \boldsymbol{y} \geq \boldsymbol{v} \\
\quad \boldsymbol{y} \geq 0
\end{array}
$$

と表される。ここで，これらを要素表示すると，

$$
\min _{P(1), \boldsymbol{u}} \mu \cdot P(1)+\sum_{i \in I} u^{i}
$$

subject to

$$
\begin{aligned}
& P_{p}(t)-P_{q}(t+1)+u^{i} \geq v_{p q}^{i}(t) \\
& \forall i \in I, \quad \forall p, q \in N, t \in T \\
& \begin{array}{c}
P(1)-P_{q}(2) \geq 0 \quad \forall q \in N \\
P_{p}(t-1)-P_{q}(t) \geq 0 \\
\boldsymbol{P} \geq \mathbf{0}, \quad \boldsymbol{u} \geq \mathbf{0}
\end{array} \quad \forall p, q \in N, t=3, \ldots T
\end{aligned}
$$

となる。単一入札の双対問題との違いは式 (29)であり, 単一入札と同様の双対変数の解釈を行うと, 個人 $i$ の 効用を表すと解釈することができる.

整数計画問題である $[\mathrm{SO}]$ とその LP 緩和問題である $\left[\mathrm{SO}-\mathrm{LP}_{\text {primal }}\right]$, その双対問題 $\left[\mathrm{SO}-\mathrm{LP}_{\text {dual }}\right]$ の目的関数 の最適值の間には, LP 緩和問題が最適解を持つとき, 次のような関係がある。

$$
[\mathrm{SO}] \leq\left[\mathrm{SO}-\mathrm{LP}_{\text {primal }}\right]=\left[\mathrm{SO}-\mathrm{LP}_{\text {dual }}\right]
$$

命題 3 の通り, 元問題の LP 緩和問題の解が整数解 して得られる保証はないが，LP緩和問題やその双対問 題は元問題の上界となっている。 そこで, これらの双 対問題の性質を利用した複数入札時の解法を提案する.

\section{6. 乗捨て型共同利用交通システムオークショ ンの解法}

\section{(1) 単一入札の解法}

単一入札のケースでは 5. (3) で示したように, 元問 題を LP 緩和した問題が整数解をもつため, LP 緩和問 題を解くことで元問題の最適解, つまり利用権オーク ションの勝者決定問題の解が得られる. 線形計画問題 は単体法や内点法などの解法が知られており，また実 用上はソルバーを用いることで高速に解を求めること が可能である.

\section{（2） 複数入札の解法}

次に複数入札の解法アルゴリズムを提案する. 最適 化問題 $[\mathrm{SO}]$ の LP 緩和問題の解の整数性は保証されて いないため, 解の整数性を有したまま LP 問題の枠組み に元問題を落とし込む必要がある。そこで, LP 緩和問 題の解と LP 緩和問題の双対問題の解を利用して, 強い
土木学会論文集D3 (土木計画学), Vol. 70, No. 4, 198-210, 2014.

制約条件を導入した新たな LP 緩和問題を生成し，最 適解を求めるというアルゴリズムを以下のように構築 する。

step.0 元問題 $[\mathrm{SO}]$ を現在の定式化として設定し, step. 1 乞.

step.1 現在の定式化に対して, LP 緩和した問題を解 く. 得られた解 $\boldsymbol{x}$ が整数解であれば終了。そうで なければ, step.2へ。

step.2 現在の定式化の LP 緩和問題の双対問題を解く. その解を $\boldsymbol{y}=(\boldsymbol{P}, \boldsymbol{u})$ とする。 ここで,

$$
u^{i}>v_{p q}^{i}(t)-\left(P_{p}(t)-P_{q}(t+1)\right)
$$

が任意の $p, q \in N, t \in T$ で成り立つ $i$ が存在する 場合，現在の定式化に

$$
\sum_{t \in T} \sum_{p q \in L} x_{p q}^{i}(t)=0
$$

という強い制約式を追加し, step.1に戻る。その ような $i$ が見つからない場合は step.3へ.

step.3 step.1の LP 緩和で得られた解 $\boldsymbol{x}$ のうち, 整 数以外の解 $x_{p q}^{i}(t)$ に対して, それぞれについて, $x_{p q}^{i}(t)=1$ を追加した子問題, $x_{p q}^{i}(t)=0$ を追加 した子問題を作成し，LP 緩和問題を解く。尒問題 の解で整数以外の解をもつとき, 更に場合分けを した子問題を作成し, 順次解を求める。最も下層 のすべての子問題が整数解のみをもつときに子問 題の作成を終了する. 解が整数解のみで構成され る子問題の中で目的関数の值が最大となる子問題 の解が元問題の解である.

このアルゴリズムで得られる解は元問題 $[\mathrm{SO}]$ の最適解 であることを示す. 元問題は整数計画問題であり, 実行 可能解集合は制約条件による多面体で表現される。整 数計画問題の許容領域の凸包は LP 緩和問題の許容領域 に包含されるため, step. 2 による双対問題を用いて強い 制約式を導入した後の実行可能解集合は元問題 $[\mathrm{SO}]$ の 最適解を含んでいる. この操作は切除平面法に対応し ている. 一方, step. 3 は整数以外の解に対して, $\{0,1\}$ の場合分けを行い子問題へと分割し, 目的関数を最大 とする整数解を順次求めているので, 分枝限定法に対 応している. 分枝限定法は整数計画問題の厳密解を求 める手法であり, step.1, step.2, step.3のどの段階で終 了したとしても, 得られた解は元問題 $[\mathrm{SO}]$ の最適解と なっている.

\section{(3) 大規模数值計算例}

上記のアルゴリズムを用いて, 大規模な乗捨て型共同 利用交通システムオークションであっても実用上，十分 な計算速度で落札者を決定できることを示そう。例とし て, (1) 入札者数 2,000 人, 車両台数 $\mu=20$, ポート数 20 , 時間帯枠数 $t=10,(2)$ 入札者数 5,000 人, 車両台 


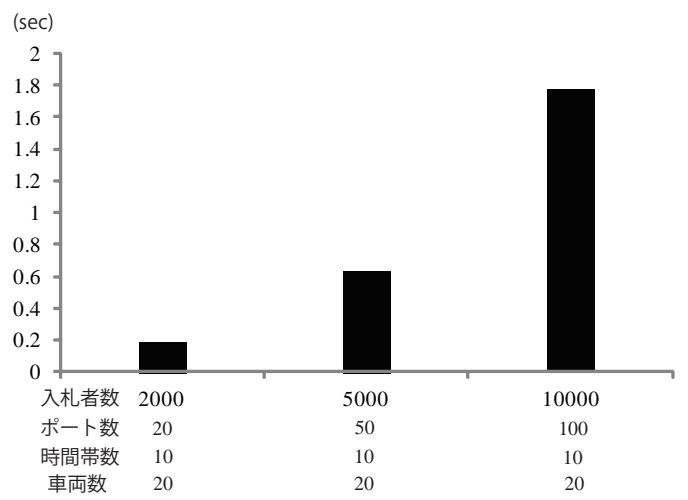

図-7 大規模計算時間の比較

数 $\mu=20$, ポート数 50 , 時間帯枠数 $t=10,(3)$ 入札者 数 10,000 人, 車両台数 $\mu=20$, ポート数 100 , 時間帯 枠数 $t=10$ の計算時間を示す。また，それぞれ非負条 件を除く制約条件式の数は (1)2181，(2)5451，(3)10901 である。計算には OS: Windowa 7 Professional, CPU: Intel Core i7-2620M (2.7GHz), メモリ 8GB の計算機 を用いた。

ランダムに発生させた評価值・OD 分布をもとにそ れぞれのケースで 10 回実施した平均值を図-7に示す。 それぞれ平均 (1)0.18 [sec]，(2)0.63 [sec]，(3)1.81 [sec] と実用上問題ない実行時間である。勝者決定問題を解 いた後, 利用権価格としての Vickrey payments を計算 する必要があるが，これも各勝者を入札者集合から抜 いて計算することで求められるため, 落札者が $n$ 人の 場合, 高々 $n$ 倍の計算時間になるのみであり, 実用上全 く問題がない. 以上より, 最適化問題 $[\mathrm{SO}]$ を現実に解 くための二つ目の問題点を解決することができた.

\section{（4）リロケーションサービスの可能性}

最後に, 乗捨て型共同利用交通システムオークション の興味深い結果の一例を示そう. 図-8, 表-4で示すよ うに, OD 需要が著しく偏つた場合を考える。このケー スで供給量制約 $\mu=1$ のとき, 割当者の評価値の総和が 最大となる割当は $t=1$ に入札者 $\mathrm{ID}=1\left(v_{12}^{1}(1)=95\right)$, $t=2$ に入札者 $\mathrm{ID}=5\left(v_{21}^{5}(2)=20\right), t=3$ に入札者 ID $=4\left(v_{12}^{4}(3)=92\right)$ であり, 総和は 207 である.

このとき，各割当者の支払額は 4 . (1) で設計した オークションの支払ルール（詳細は付録参照）に基づ くと,

$$
P^{i}(\boldsymbol{z})=W\left(0, \boldsymbol{z}^{-i}\right)-W^{-i}(\boldsymbol{z})
$$

で表すことができる，ただし，W(.) は入札值べクトル による割当結果の下での割当者による入札值の和を表 し, $W^{-i}(\cdot)$ は $W(\cdot)$ の割当結果から個人 $i$ を取り除い た場合の割当者による入札值の和を表す。このとき，各

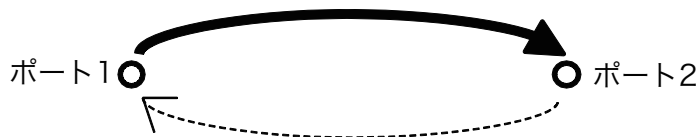

図-8 OD 需要が偏つた場合

表-4 OD 需要が偏つた場合の入札者集合

\begin{tabular}{ccccc}
\hline 入札者 & $\mathrm{OD}$ & $v(t=1)$ & $v(t=2)$ & $v(t=3)$ \\
\hline 1 & $1 \rightarrow 2$ & 95 & 90 & 85 \\
2 & $1 \rightarrow 2$ & 82 & 92 & 72 \\
3 & $1 \rightarrow 2$ & 74 & 86 & 61 \\
4 & $1 \rightarrow 2$ & 60 & 80 & 92 \\
\hline 5 & $2 \rightarrow 1$ & 30 & 20 & 10 \\
\hline
\end{tabular}

個人の支払額は

$$
\begin{aligned}
& P^{1}=(82+20+92)-(20+92)=82 \\
& P^{5}=(95)-(95+92)=-92 \\
& P^{4}=(95+20+72)-(95+20)=72
\end{aligned}
$$

となる。これは第 1 項がその個人が入札しなかった場合 の評価值を最大とする割当て時の評価值の総和を表し ており，入札者 ID $=5$ がいない場合は ID $=1$ がポー ト 1 からポート 2 へ移動した後, 車両がポート 1 へ戻 ることができないため, $t=2,3$ の時間帯に利用され ないことを表している. しかし, 入札者 ID $=5$ が存在 することで車両がポート 1 へ戻り, 入札者 $\mathrm{ID}=4$ が利 用できるため, 入札者 ID $=5$ が与える正の外部性はシ ステムにとって非常に大きい. その結果が -92 という 負の支払額（つまり, 収益）として利用権価格に反映 されている.

このように乗捨て型共同利用交通システムの利用権 オークションは本来シェアリングシステムが抱える再 配車の問題を利用者間を単純に繋ぐだけでなく, 正の 収益を与えて需要の平準化を行う性質もメカニズムの 中に内在化させている。そそのため，もし社会の中に配 車を行って正の利潤を得たい利用者が存在すれば， 0 以 下の評価值で入札することで, 正の利潤を得ることが でき, また出発地需要の高いポートに車両を移動させ ることで社会的余剩を高めることが可能である.

\section{7. おわりに}

本研究の結果をまとめる，まず，本研究では乗捨て 型共同利用交通システムという新たな交通サービスを 定義し，その問題点を解決するための利用権取引制度 を提案した。乗捨て型共同利用交通システムの利用権 取引制度によって社会的最適状態を達成するためには (1) 利用者の評価值の正直表明性, (2) 最適割当問題の $\mathrm{NP}$ 困難性を解決する必要がある。そこで, (1) を解決 
するために乗捨て型共同利用交通システムに対する利 用権オークションの VCG メカニズムを設計した.

(2) の問題点に対し, 利用者の入札行動を複数入札時 と単一入札時の 2 つの場合を考元, 数学的に良い性質 がある単一入札のケースを元に，乗捨て型共同利用交 通システムの利用権オークションという問題の数学的 構造を解析した。この結果, 単一入札のケースでは LP 緩和した問題で元問題と同じ整数解が得られることを 示した。また，乗捨て型共同利用交通システムの利用権 価格はポート出発時の支払額とポート到着時の収益に 分解され, 各利用者は車両移動の外部性によってサー ビスの消費者であり，生産者でもあることを示した。

最後に, 複数入札時における問題の解法として LP 緩 和と双対問題を用いた解法アルゴリズムを提案し，そ のアルゴリズムによって実適用を想定した大規模な問 題設定においても十分高速に求解が行えることを示し た。また，車両移動の外部性が生み出す負の価格の存 在も示し, リロケーションサービスの可能性も示した. 以上より, (2) の問題点も解決し, 乗捨て型共同利用交 通システムの利用権取引制度の実現可能性を明らかに した.

このように，乗捨て型共同利用交通システムを利用 権オークションによって最適割当と価格設定を理論的 に実現可能であることを示したが，現実空間で実施す る際には残された課題が存在するため, 今後の課題と して整理する．1点目はサービス利用予定者は事前に利 用権に対して入札を行い，オークションに参加する必 要があるが, 現実には突発的なトリップ需要の発生が 存在し，全ての利用権を事前に割り当てることによる 非効率性が新たに発生しうる。本研究で提案したバッ チ型のメカニズムではない, オンラインメカニズムを 考案することが実適用には必要である. 2 点目は利用権 のキャンセルについてである. 本研究ではキャンセル を許容しない (OD 接続性のために必ず利用する必要が ある）というシステム側の要求があるが，これらを緩 和するような利用権の在り方やメカニズム設計も実適 用のためには重要である。 3 点目は各利用者のトリップ が 1 回に制限されていないケース (往路・復路の組合せ 入札)における最適なオークションメカニズムの設計で ある。これらは本研究で扱った問題構造以上に複雑な 組合せ最適化問題の構造となるが，現実には上記のよ うな交通需要は自然であり, これらに対処するメカニ ズム, 割当・価格の計算方法の構築が必要と考えられ る。最後に, 交通サービス利用予定者にサービス利用 権に対する入札行動を前提としたメカニズムを設計す ることは，入札に対する取引費用や評価值に対する認 知負荷などの観点から社会的受容性はまだまだ低いと 考えられる。実社会への適用のために，これらに関し
土木学会論文集D3 (土木計画学), Vol. 70, No. 4, 198-210, 2014.

ても検討を行う必要がある。

謝辞： 本研究を進めるにあたって, 東北大学 赤松隆 教授から有益なコメントを頂いた。 また，匿名の査読 者より有益なコメントを頂いた。本研究は JSPS 科研 費若手 B (課題番号: 25820236 , 課題名: 交通需要誘出 を内生化するメカニズムデザインの理論的・実験的ア プローチ)の助成を受けた。記して感謝したい.

\section{付録 I 命題 1 の証明}

\section{（1）真の評価値 $v$ で入札された場合の効率性の証明}

式 (6), (9), (7)，(8)，(10)，(11)ょり，vで入札したと き，制約条件下で入札值の和を最大化した状態は定義 上, 社会的最適状態である。 よって, 真の評価值で入 札される限り, 効率性が満たされる。

\section{（2）耐戦略性についての証明}

全入札者による入札值ベクトルを $\boldsymbol{z}$, 入札値ベクト ル $\boldsymbol{z}$ の条件下で, 割当者による入札值の和を最大にす る割当を表すべクトルを $S(\boldsymbol{z})$ とし, $S^{i}(\boldsymbol{z})=\{0,1\}$ は 個人 $i$ の割当結果を表すとする。このとき, VCG メカ ニズムにおける個人 $i$ の支払額 $P^{i}(z)$ は次の式で表さ れる。

$$
P^{i}(\boldsymbol{z})=W\left(0, \boldsymbol{z}^{-i}\right)-W^{-i}(\boldsymbol{z})
$$

ここで, $z^{-i}$ は個人 $i$ 以外の入札者の入札值ベクトル, $W(\cdot)$ は入札值ベクトルによる割当結果 $S(\cdot)$ の下での 割当者による入札值の和を表し, $W^{-i}(\cdot)$ は $W(\cdot)$ の割 当結果から個人 $i$ を取り除いた場合の割当者による入 札值の和を表す。この支払額はVickrey payment と呼 ばれ, 個人 $i$ が $z^{i}$ の入札值ベクトルで入札することで, システム全体の効率性（個人 $i$ 以外の入札者による社 会的余剩）に与える外部性を表す。

個人 $i$ 以外の入札者は真の評価值ベクトル $v^{-i}$ で入 札している状況を考えるとき, 個人 $i$ が真の評価値 $\boldsymbol{v}^{i}$ で入札したときの利得は

$$
\begin{aligned}
\boldsymbol{v}^{i} \cdot S^{i}(\boldsymbol{v})-P^{i}(\boldsymbol{v}) & =\boldsymbol{v}^{i} \cdot S^{i}(\boldsymbol{v})+W^{-i}(\boldsymbol{v})-W\left(0, \boldsymbol{v}^{-i}\right) \\
& =W(\boldsymbol{v})-W\left(0, \boldsymbol{v}^{-i}\right) \geq 0
\end{aligned}
$$

であり, 利得は 0 以上のため, 個人合理性を満たす。個 人 $i$ が真の評価值以外の入札值 $\boldsymbol{z}^{i}$ で入札したときの利 得は

$$
\begin{aligned}
\boldsymbol{v}^{i} & \cdot S\left(\boldsymbol{z}^{i}, \boldsymbol{v}^{-i}\right)-P^{i}\left(\boldsymbol{z}^{i}, \boldsymbol{v}^{-i}\right) \\
= & \boldsymbol{v}^{i} \cdot S\left(\boldsymbol{z}^{i}, \boldsymbol{v}^{-i}\right)+W^{-i}\left(\boldsymbol{z}^{i}, \boldsymbol{v}^{-i}\right)-W\left(0, \boldsymbol{v}^{-i}\right)(\mathrm{I} .3)
\end{aligned}
$$


である. 式 (I.2) から (I.3) を引くと

$$
\begin{aligned}
\boldsymbol{v}^{i} & \cdot S(\boldsymbol{v})-P^{i}(\boldsymbol{v})-\boldsymbol{v}^{i} \cdot S\left(\boldsymbol{z}^{i}, \boldsymbol{v}^{-i}\right)+P^{i}\left(\boldsymbol{z}^{i}, \boldsymbol{v}^{-i}\right) \\
& =W(\boldsymbol{v})-\boldsymbol{v}^{i} \cdot S\left(\boldsymbol{z}^{i}, \boldsymbol{v}^{-i}\right)-W^{-i}\left(\boldsymbol{z}^{i}, \boldsymbol{v}^{-i}\right) \\
& =W(\boldsymbol{v})-W\left(\boldsymbol{z}^{i}, \boldsymbol{v}^{-i}\right)-\left(\boldsymbol{v}^{i}-\boldsymbol{z}^{i}\right) \cdot S\left(\boldsymbol{z}^{i}, \boldsymbol{v}^{-i}\right)(\text { I. } 4)
\end{aligned}
$$

が成り立つ.ここで, $S^{i}(\boldsymbol{v})=1$ のとき，つまり，個人 $i$ が真值で入札した場合に落札できるとき， $\boldsymbol{v}^{i} よ り$ 低 い入札值 $\boldsymbol{z}^{i}$ で入札すると, $\boldsymbol{z}^{i}<\boldsymbol{v}^{j}<\boldsymbol{v}^{i}$ が存在し, 個 人 $i$ が落札できない場合, 式 (I.4) $=\boldsymbol{v}^{i}-\boldsymbol{v}^{j}>0$, そ のような $\boldsymbol{v}^{j}$ が存在しない場合は式 (I.4)=0であるの で, 式 (I.4) $\geq 0$ が成り立つ.一方, $S^{i}(\boldsymbol{v})=0$ のとき, つまり，個人 $i$ が真值で入札した場合に落札できない とき, $\boldsymbol{v}^{i} よ り$ 高い入札值 $\boldsymbol{z}^{i}$ で入札し, 個人 $j$ の割当 を個人 $i$ の割当へと変更して落札できた場合, 式 (I.4) $=\boldsymbol{v}^{j}-\boldsymbol{z}^{i}-\left(\boldsymbol{v}^{i}-\boldsymbol{z}^{i}\right)=\boldsymbol{v}^{j}-\boldsymbol{v}^{i}>0$ が成り立つ. 上記 の関係式より，真の評価值で入札した場合の利得は必 ずそれ以外の入札值で入札した場合の利得以上である ため, 自身の真の評価值で入札することは弱支配戦略 となる．これはすべての入札者にとって成り立つため, 以上より，耐戦略性が満たされる。

\section{(3) 効率性についての証明}

$(1),(2) よ り$ 全ての利用者は真の評価值で入札し, 効 率性が満たされる。

\section{参考文献}

1) 赤松隆，佐藤慎太郎，Nguyen Xuan Long：時間帯別ボ トルネック通行権取引制度に関する研究, 土木学会論文 集 D, Vol.62, No.4, pp.605-620， 2006.

2) 赤松隆：一般ネットワークにおけるボトルネック通行権 取引制度，土木学会論文集 D, Vol.63, No.3, pp.287-301， 2007.

3) 和田健太郎, 赤松隆: 単一ボトルネックにおける渋滞と 混雑を解消する情報効率的メカニズムの設計，土木学会 論文集 D, Vol.66, No.2, pp.160-177, 2010.
4) 和田健太郎, 赤松隆:ネットワーク通行権取引市場のオー クション・メカニズム，土木学会論文集 D, Vol.67, No.3, pp.376-389, 2011.

5) Porter, D., Torma, D. P., Ledyard, J. O., Swanson, J. A. and Olson, M.: The First Use of a CombinedValue Auction for Transportation Services, Interfaces, Vol.32, No.5, pp. 4-12, 2002.

6) Moore, W. E., Warmke, J. M. and Gorban, L. R.: The Indispensable Role of Management Science in Centralizing Freight Operations at Reynold Metals Company, Interfaces, Vol.21, No.1, pp.107-129, 1991.

7) Caplice, C. and Sheffi, Y.: Optimization Based Procurement for Transportation Services, Journal of Business Logistics, Vol.24, No.3, pp.109-128, 2003.

8) Ball, M. O., Donohue, G. L. and Hoffman, K.: Auctions fot the Safe, Efficient, and Equitable Allocation of Airspace System Resources, In: Cramton, P., Shoham, Y., Steinberg, R. (eds), Combinatorial Auctions, MIT Press, pp.507-538, 2006.

9) Vickrey, W.: Counter speculation, auctions, and competitive sealed tenders, Journal of Finance, Vol.16, pp.8-37, 1961.

10) Clarke, E. H.: Multipart Pricing of Public Goods, Public Choice, Vol.11, pp.17-33, 1971.

11) Groves, T.: Incentives in Teams, Econometrica, Vol.41, pp.617-631, 1973.

12) Krishna, V. and Perry, M.: Efficient Mechanism Design, Mimeo, Penn. State University, 1998.

13) Blumrosen, L. and Nisan, N.: Combinatorial Auctions, Algorithmic Game Theory, Cambridge University Press, 2007.

14) Vohra, R. V.: Mechanism Design: A Linear Programming Approach, Cambridge University Press, 2011.

15) Bikhchandani, S. and Ostroy, J. M.: The Package Assignment Model, Journal of Economic Theory, Vol.107, No.2, pp.377-406, 2002.

16) B. コルテ, J. フィーゲン: 組合せ最適化一理論とアル ゴリズム 第 2 版，シュプリンガージャパン， 2009.

17) Hoffman, A. J. and Kruskal, J. B.: Integer boundary points of convex polyheedra, Annals of Mathematics Study, No.38, Princeton University Press, Princeton, pp.233-246, 1956.

(2013. 7. 19 受付)

\title{
DESIGN OF A TRADABLE PERMIT MECHANISM FOR MOBILITY-SHARING AND ITS SOLUTION ALGORITHM
}

\author{
Yusuke HARA and Eiji HATO
}

In this study, we propose a tradable permit mechanism for mobility sharing system. if mobility sharing services allow users to take arbitrary trips, the overall efficiency of the service cannot be achieved. To solve this problem, this study proposes a tradable permit mechanism. We first propose the Vickrey-ClarkeGroves mechanism for mobility sharing. With this mechanism, this tradable permits system satisfies the strategy-proof and the efficient allocation. Next, we discuss the difference between single-minded bidders case and multiple bidders case. we show that the permits price is decomposed to the usage fee for leaving the port of origin and the income for arriving at the port of destination. Finally, we propose the solution algorithm of these problems and from the aspect of computational time, we show this algorithm is feasible. 